${ }^{2}$ WSL Swiss Federal Research Institute, Birmensdorf, Switzerland

\title{
Climate change may already threaten Scots pine stands in the Swiss Alps
}

\author{
M. Rebetez ${ }^{1}$ and M. Dobbertin ${ }^{2}$ \\ With 6 Figures \\ Received November 6, 2003; revised March 2, 2004; accepted March 9, 2004 \\ Published online July 14, 2004 (C) Springer-Verlag 2004
}

\begin{abstract}
Summary
Large numbers of Scots pine are dying in the dry inner-alpine valleys of the European Alps; in Switzerland, locally almost half the Scots pine (Pinus sylvestris L.) population has died since 1995. As Switzerland's temperature has increased at more than twice the global average in the $20^{\text {th }}$ century and as most of this increase has occurred during the last 20 years, we investigated possible relationships between the dying Scots pine and climatic parameters. We centred our studies in the upper Rhone valley.

Our results show that the strong climatic warming that has occurred in recent years may well be the indirect cause of the mortality observed in these forests. Tree mortality was highest following the dry and hot year 1998, and tree defoliation, an indicator of tree vitality, showed a strong correlation with the previous year's precipitation. While precipitation showed no clear significant trend over time, the number of warm days (mean $>20^{\circ} \mathrm{C}$, maximum $>25^{\circ} \mathrm{C}$ ) and potential evapotranspiration have significantly increased over the last 20 years.

Higher temperatures favour pine wood nematodes and bark beetles, both of which are found at the study site, and increasing drought stress reduces tree resistance against pathogens. As these forests have in part protective functions, there is a need to better understand the mortality through interdisciplinary research and also to find means to change the species composition in order to establish tree species that are better able to withstand warmer temperatures.
\end{abstract}

\section{Introduction}

Scots pine (Pinus sylvestris L.) forests commonly cover the lower slopes of dry inner-alpine valleys of the European Alps. Unusually high tree mortality of Scots pine has recently been observed in several of these inner-alpine valleys (Vertui and Tagliaferro, 1998; Cech and Perny, 1998). In the Swiss Rhône Valley in particular, locally half of the Pinus sylvestris L. died between 1995 and 2000 (Rigling and Cherubini, 1999; Dobbertin, 1999). At lower altitudes Scots pine occurs here close to the southern limits of its natural geographic distribution. As Switzerland's temperature has increased at more than twice the global average in the $20^{\text {th }}$ century and as most of this has happened during the last 20 years (Rebetez, 2001; Frei et al., 2001; Rebetez, 1999), we investigated possible relationships between climatic parameters, tree defoliation, which is an indicator of tree vitality, and the mortality rate of Scots pine in the region of Visp in the upper Rhône Valley.

Episodes of Scots pine decline in the Swiss Rhône valley have been reported throughout the $20^{\text {th }}$ century, mainly related, as with the decline of apricot trees, to fluorine emissions from aluminium factories (Faes, 1921; Kienast, 1982; Kontic et al., 1986). Since the late 1930s, pine declines have also been observed in areas further away from the pollution source (Scherrer, 1988). However, following the installation of filter systems at the beginning of the 1980s, fluorine 
emissions have been significantly reduced (Rickli et al., 1989) and no further tree declines have been reported. Starting in the 1990s, an increased worsening of the health of pines has been observed, combined with an increase in the area affected by decline, and culminating in a new pine dieback episode beginning in 1998 (Rigling, 1999; Dobbertin, 1999; Rigling et al., 1999). Although various potentially harmful beetles (mostly bark beetles such as Tomicus piniperda L., Tomicus minor Htg., Ips accuminatus Gyll. and the Buprestidae beetle species Phaenops cyanea $F$.), stem infection fungi and branch fungi have been identified on dying trees (Rigling et al., 1999; Dobbertin, 1999; Carron, 2000), the exact causes of the present mortality episode have not been established and are currently under investigation (Rigling et al., 2001).

The distribution of mortality within the valley appears to be changing. Pine mortality was previously found to be highest in the valley bottom close to the pollution sources and decreased with altitude and distances to pollution sources (Scherrer et al., 1981). Recently, pine mortality has been observed to be moving upward on the valley side-slopes and was found far from any pollution sources (Scherrer, 1988; Rigling et al., 1999).

While mortality rates have not yet been related to climatic conditions, Rigling and Cherubini (1999) have analysed annual tree ring width in Scots pine using tree cores or stem disks. They have found that drought periods from April to June of the current year and mean temperature from April to August were the most significant variables (both negatively correlated) explaining tree growth at a study site south-east of Visp. For trees sampled west of Visp, Rigling et al. (2001) found that precipitation in April and May positively influenced ring width, while mean temperature in June had a negative correlation. Periods of high needle loss have also been found to coincide with periods of prolonged drought (Pouttu and Dobbertin, 2000).

In nearly all reports on pine decline in the inner-alpine valleys, drought has been reported prior to the decline episode and considered as a triggering factor (Kienast, 1982; Vertui and Tagliaferro, 1998; Cech and Perny, 1998; Rigling and Cherubini, 1999; Dobbertin, 1999). However, most authors do not consider drought as the main factor in the decline, as Scots pine is known to be very drought-resistant and other less drought resistant trees are not affected (Vertui and Tagliaferro, 1998; Cech and Perny, 1998; Rigling and Cherubini, 1999).

Nevertheless, it is well-established that drought is increasing the susceptibility of pines to secondary pathogens and that warm spring and summer temperatures are increasing the reproductive rate of bark beetles (Wermelinger and Seifert, 1998, 1999) and pine wood nematodes (Rutherford and Webster, 1987; Bakke et al., 1991). Tomiczek (1996) has shown that pine wood nematodes (Bursaphelenchus mucronatus) are involved in the continuing Scots pine decline process in lower Austria, and we suspect that pine wood nematodes may also be playing a role in our study area. In Japan, introduced pine wood nematodes (Bursaphelenchus xylophilus) have caused extensive damage to pine stands (Mamiya, 1988) leading to a shift in dominant tree species (Fujihara, 1996). Pine mortality in Japan shows a strong positive correlation with summer temperature (Rutherford and Webster, 1987). While the more aggressive B. xylophilus has so far not been found in the Rhône Valley, two other potentially harmful nematodes have recently been identified in dying Scots pine in the Rhone valley: $B$. mucronatus and a newly described Bursaphelenchus species (U. Schönfeld and H. Braasch, pers. comm.).

In our study we examined meteorological and biological data. We analysed the relationship between current tree mortality or tree vitality changes on one hand and climatic parameters concerning summer temperature and drought on the other, and we looked for temporal trends.

\section{Material and methods}

Since 1996, we have been measuring annual mortality rates of Scots pines in a 2-ha study site at Visp and we have assessed crown defoliation annually on a 0.5 ha subplot. The site is located on a steep north-facing slope close to the valley floor at around $750 \mathrm{~m}$ asl (Fig. 1). The uneven-aged forest (30-70 years in age) is composed of $80 \%$ Scots pines and $20 \%$ broadleaves. With the help of reference photographs, defoliation was assessed in $5 \%$ classes, comparing each tree to a fully foliated reference tree $(0$ defoliation $=$ fully foliated, $100 \%$ 


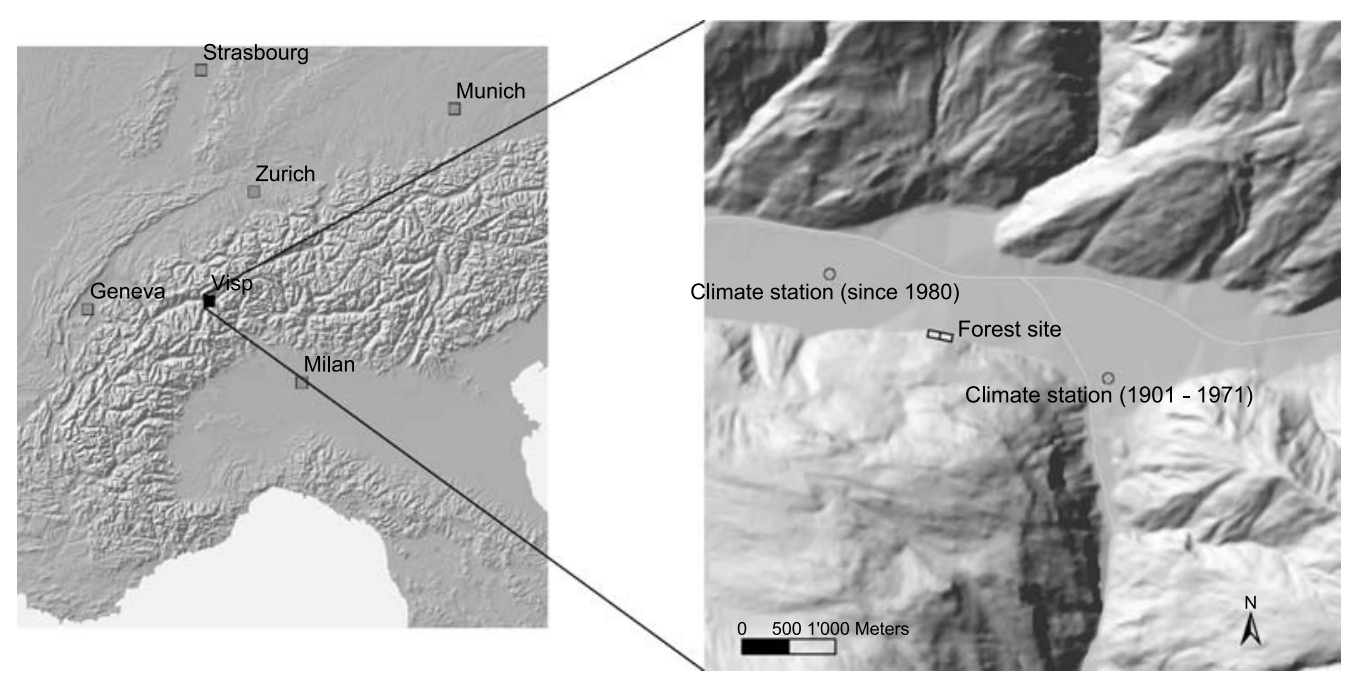

Fig. 1. Map of the Alps and of the Visp region with the forest site and the two climate stations. (Topographic data: DHM25 (C) 1995 Bundesamt für Landestopographie)

defoliated = dead; Müller and Stierlin, 1990). Two teams assessed the trees each year at the end of July without knowledge of previous assessments for those trees. For all surviving trees (39 pines and 34 broadleaves) the changes in foliage percent were computed for all subsequent years. All measurements on this monitoring site, including the assessments of tree mortality rates and defoliation, were performed within the Swiss long-term forest ecosystem monitoring programme (LWF).

Data for temperature, precipitation, potential evapotranspiration and relative air humidity originate from the nearby meteorological station of Visp, which has been part of the MeteoSwiss net since 1980. We also used earlier precipitation data from an older MeteoSwiss station also located in Visp, $2.5 \mathrm{~km}$ from the present site, offering data from 1901 to 1971 (Fig. 1). Although the difference in location means that the two series cannot be homogenized, the data allow interesting comparisons.

We compared the precipitation sum of the twelve months prior to tree assessments with the change in tree foliage percentage using standardized values. The annual difference in the mean precipitation or change in foliage values of the six-year period were calculated as a percent of the maximum absolute change.

We analysed monthly and annual precipitation data in order to see if recent years have been particularly abnormal and if there were long-term trends in these data. We also looked for changes and trends in the potential evapotranspiration and air humidity data. Potential evapotranspiration was measured between April and September from 1981 to 2000 using Wild's scales.

For temperature, we selected thresholds that have been reported in the literature as being potentially limiting for Scots pine or favourable for potentially threatening pathogens (Rutherford and Webster, 1987; Rutherford et al., 1990; Wermelinger and Seifert, 1999). As Rutherford and Webster (1987) consider the $20^{\circ} \mathrm{C}$ July isotherm to be the limiting factor for the natural range of pines that are vulnerable to pine wood nematodes, we analysed the number of days with a mean temperature of $20^{\circ} \mathrm{C}$ or more. As $25^{\circ} \mathrm{C}$ has been found in experiments to be critical for the development of the potentially pathogenic nematode Bursaphelenchus mucronatus (Braasch, 1996; Bakke et al., 1991), we also analysed this threshold. As the maximum temperature measurements were not available, we used the temperature measured at $1.00 \mathrm{pm}$.

\section{Results}

We have been observing 411 pines with a diameter at breast height in 1996 of at least $12 \mathrm{~cm}$. Between March 1996 and June 2002, 178 of these 411 pines (43\%) died. Mortality was highest between July 1998 and July 1999 (Fig. 2). 


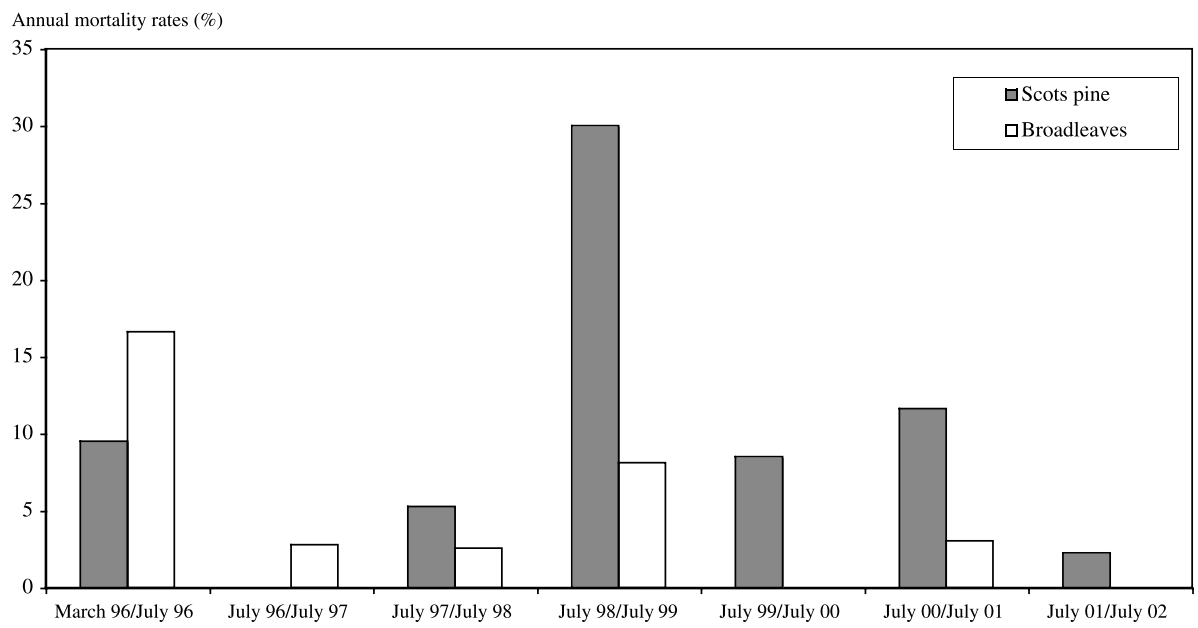

Fig. 2. Annual mortality rates for Scots pines in the 2-ha study site of Visp
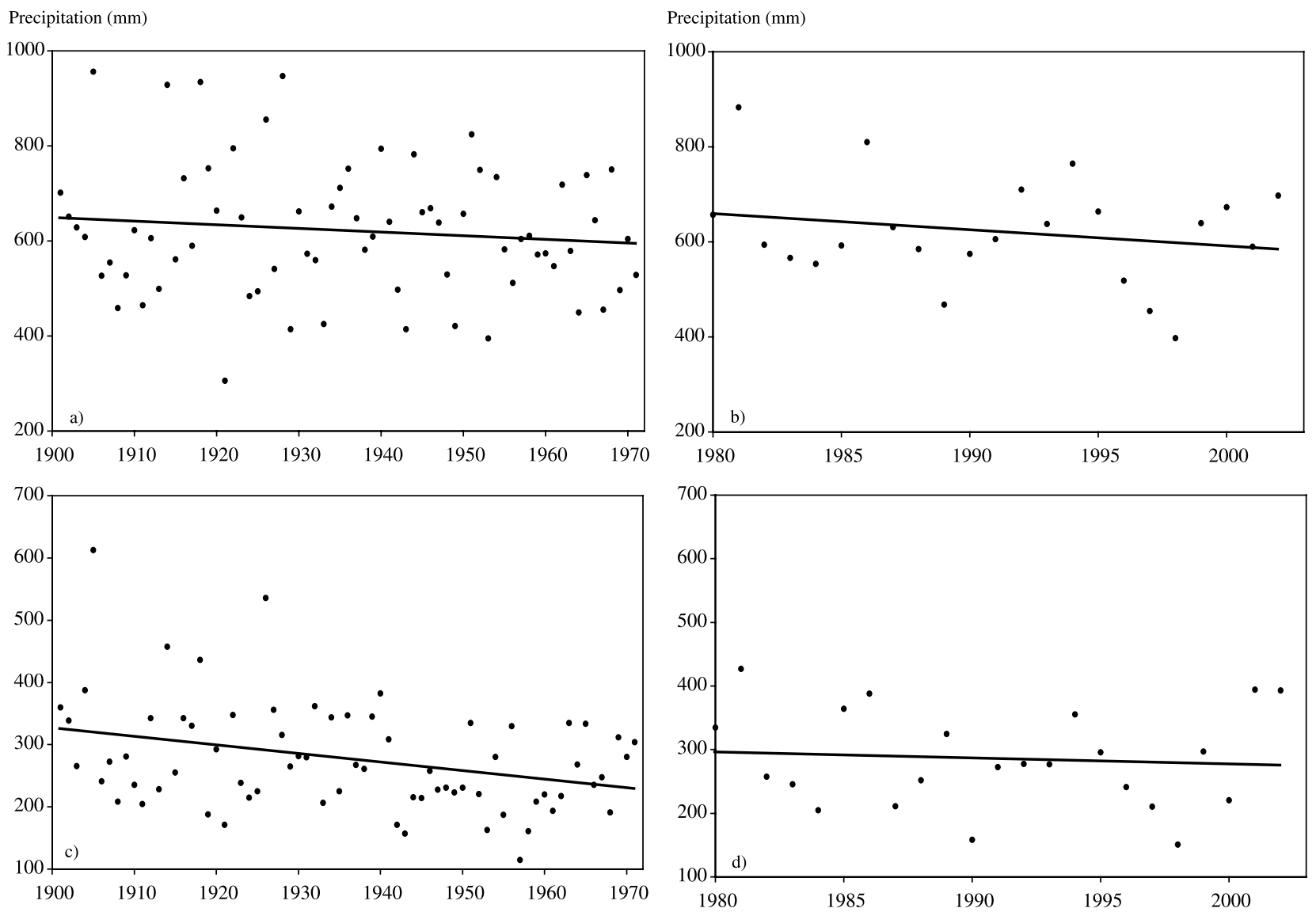

Fig. 3. Precipitation [mm] in Visp, 1980-2002 (b+d), and for the old Visp meteorological station, 1901-1971 (a+c). Annual values $(\mathbf{a}+\mathbf{b})$ and March to August sum $(\mathbf{c}+\mathbf{d})$. The amount of precipitation was particularly low in 1998 $(397 / 150 \mathrm{~mm})$. Compared to 1998 , similar and even lower values have already been measured in the past: $306 \mathrm{~mm}$ in 1921, $395 \mathrm{~mm}$ in 1953 and hardly more than $400 \mathrm{~mm}$ in 1929, 1933, 1943 and 1949 for annual values. For March to August sums: $115 \mathrm{~mm}$ in 1957, 171 in 1921, 157 in 1943, 163 in 1953, or 161 in 1958

Over the same six-year period, only 13 percent of the deciduous trees, most of them drought-sensitive birch and cherries, died.
The analysis of annual precipitation values from 1980 to 2002 (Fig. 3b) shows that the light decrease in the total amount of precipitation 
Relative change (\% of absolute maximum)

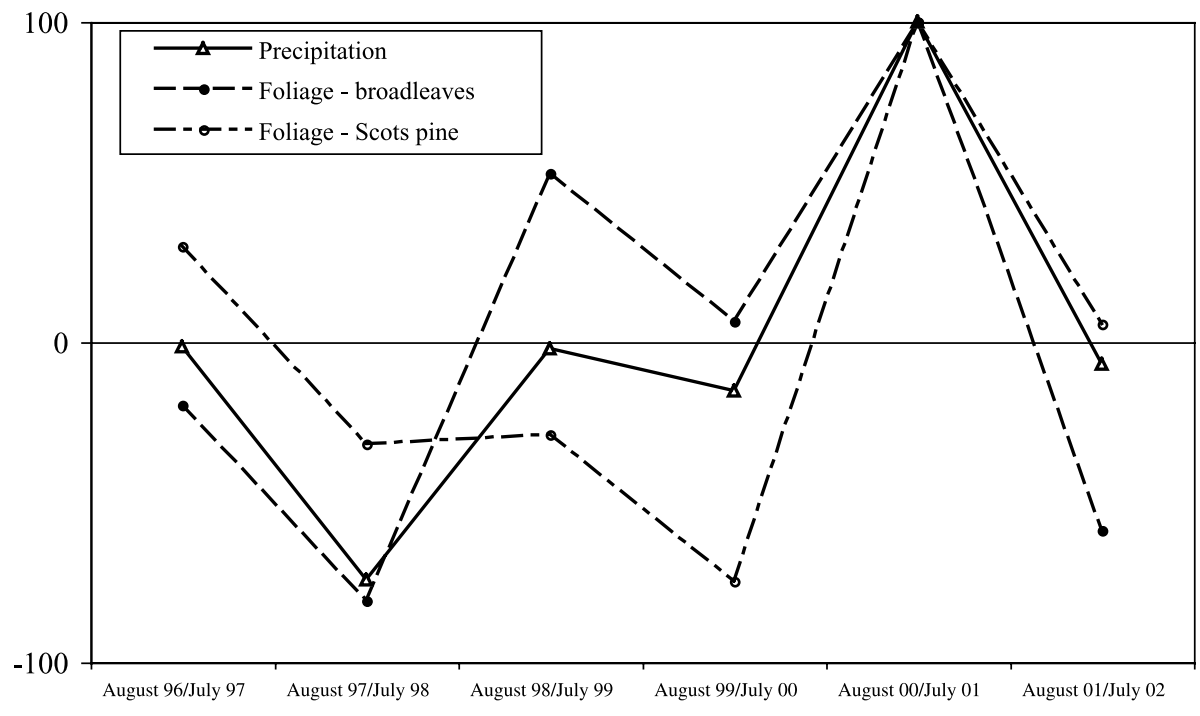

Fig. 4. Relative changes in percent of the maximum changes during 1996 and 2002 for precipitation sum (period August-July) and crown defoliation scores for broadleaves $(n=34)$ and Scots pines $(\mathrm{n}=39)$ on a 0.5 ha subplot of the LWF site Visp since 1980 is not significant. The March to August precipitation series also shows a very light not significant decrease per year (Fig. 3d). The analysis of the 1901-1970 series (Fig. 3a and c) reveals that a trend of decreasing precipitation has been evident throughout the $20^{\text {th }}$ century, averaging $0.8 \mathrm{~mm}$ per year for the annual precipitation (Fig. 3a) and $1.4 \mathrm{~mm}$ per year for the March to August precipitation (Fig. 3c). These precipitation series exhibit high variability, with year-toyear fluctuations of $100 \%$ or more. Because of this variability, neither of the precipitation trends is significant in the sense of Fisher's test.

The recent series (Fig. 3b) also shows that the amount of precipitation was extremely low in 1998, with $397 \mathrm{~mm}$ compared to a mean annual amount of $620 \mathrm{~mm}$ during the last 23 years and $150 \mathrm{~mm}$ only from March to August (Fig. 3d), compared to an average amount of $285 \mathrm{~mm}$. A more detailed analysis of the 1998 season shows that precipitation amounts were lower than average during every month from August 1997 until August 1998. During the year from September 1997 until August 1998, the total amount of precipitation reached only $369 \mathrm{~mm}$. The precipitation amount in 1998 was the lowest of the last 20 years but it was not unique, with years such as 1921 and 1953 also exhibiting annual amounts lower than $400 \mathrm{~mm}$ (only $306 \mathrm{~mm}$ in 1921). Very low precipitation sums from March to August have also occurred in the past.

The relative change in foliage of the annually assessed Scots pines (39 trees) and deciduous trees (34) that have survived the drought, reveals a strong correlation with the relative deviance in precipitation of the 12 months prior to the assessments (Fig. 4). During dry years, both pines and deciduous trees reduce their foliage, whereas during wet years they increase their foliage.

The temperature analyses reveal that the number of days with a mean temperature higher than $20^{\circ} \mathrm{C}$ has dramatically increased since 1980 (Fig. 5). The number of days higher than the threshold has more than doubled in 23 years, rising from an average of 20 days per year in 1980 to an average of more than 40 days in 2002 , despite a very low number of hot days in the summer of 2002, i.e. during the last year of this series. This trend is highly significant in the sense of Fisher's test $(\mathrm{p}<0.001)$. The highest value was reached in 1998, with 49 days with a mean daily temperature higher than $20^{\circ} \mathrm{C}$.

The number of days with temperature at $1.00 \mathrm{pm}$ higher than $25^{\circ} \mathrm{C}$ has also increased, rising from less than 30 days per year in 1980 to 45 days per year in 2002 , an increase of 0.8 days per year. This trend is also significant in the sense of Fisher's test $(p<0.001)$. Although 1998 was particularly hot, with 48 days reaching a temperature higher than $25^{\circ} \mathrm{C}, 1998$ did not reach the absolute highest value of the last 23 years as 1991 had 52 days higher than $25^{\circ} \mathrm{C}$.

The potential evapotranspiration data show a highly significant $(\mathrm{p}<0.001)$ strongly increasing trend (Fig. 6). The increasing rate corresponds to $9.4 \mathrm{~mm}$ per decade and summer month, 
Days with Mean $\mathrm{T}>20^{\circ} \mathrm{C}$

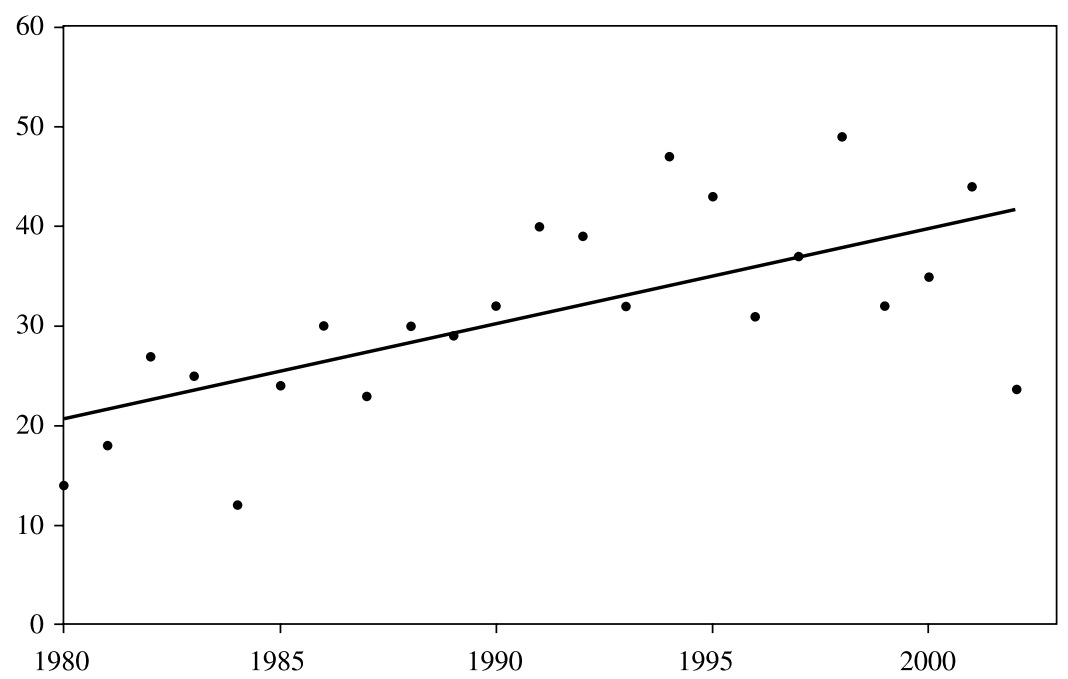

Pot. Evapotranspiration (mm)

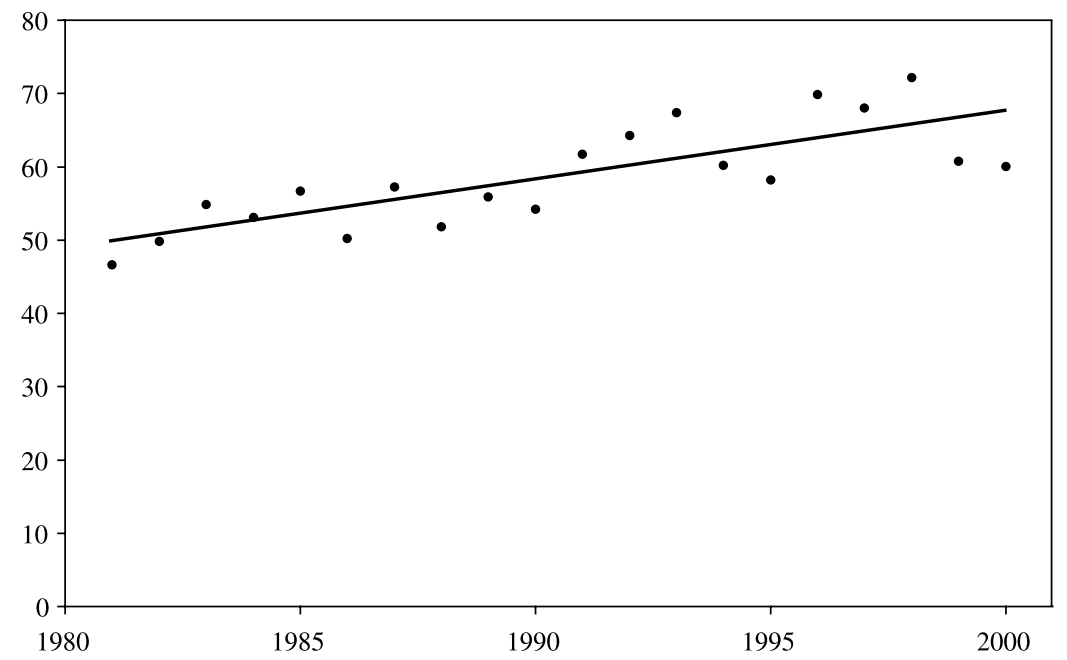

Fig. 5. Number of days with mean temperature higher than $20^{\circ} \mathrm{C}$. The increasing trend is highly significant $(\mathrm{p}<0.001)$. The increasing rate corresponds to 10 days per decade

Fig. 6. Potential evapotranspiration [mm] in Visp from 1980 to 2000 (April to September mean monthly values). The increasing trend is highly significant $(\mathrm{p}<$ $0.001)$. The increasing rate corresponds to $9.4 \mathrm{~mm}$ per decade. 1998 has reached the highest value with $72 \mathrm{~mm}$

stretching from $50 \mathrm{~mm}$ in 1980 to more than $65 \mathrm{~mm}$ in 2000. The highest value of the series $(72 \mathrm{~mm})$ was obtained in 1998.

The analysis of annual relative humidity exhibits a non-significant decreasing trend due to highly variable values. 1998 had the lowest value of the series.

\section{Discussion}

The mortality rates that we have observed are substantially higher than those previously reported in the region. The earliest review of Scots pine forests (Hess, 1942) did not mention any unusual pine mortality, suggesting that tree mortality was unimportant in the middle of the $20^{\text {th }}$ century. Scherrer (1988) reported a mortalityinduced salvage-cutting rate of 10 percent of the overall standing volume between 1941 and 1945 in the pine forests east of Visp (comparable to the LWF-Site Visp). For a more recent period, comparing two sets of aerial photographs from $1977 / 78$ and 1985 , they found a mortality rate of 16 trees per ha over the 8 years. These figures are clearly lower than the rates of $43 \%$ of the trees and 89 trees per ha between 1996 and 2002, which we have observed at the LWF-site.

As has been found in other studies (Raison et al., 1992; Zierl, 2000), pines and deciduous trees in Visp appear to be reacting strongly to below-average rainfall with decreased foliage, and to above-average rainfall with increased 
foliage. Premature leaf or needle fall is a way for trees to reduce transpiration under drought stress (Kozlowski et al., 1991). The relatively strong tree reaction at Visp shows that drought stress is an important factor at this site and that it can lead to longer-lasting defoliation (Pouttu and Dobbertin, 2000). Dobbertin and Brang (2001) showed that mortality rates increase exponentially with increasing defoliation. Given the same defoliation, pines at Visp, however, showed a 40 times higher mortality rate than is commonly observed in Switzerland (Dobbertin, 1999). Predicting tree mortality rates for Scots pines in the Rhone valley from tree rings, Bigler et al. (2004) found reduced tree growth and increased risk of tree mortality in drought years. The growth reductions and mortality risks were prolonged during multi-year droughts such as has been observed between 1996 and 1998 in Visp.

The analysis of meteorological parameters shows no statistically significant trend in the precipitation data, although a slightly decreasing trend can be detected. Most striking is the extremely high variability that is present in these data, whether in the recent or older series. The annual amount of precipitation can easily double from one year to the next, offering humid years with more than $800 \mathrm{~mm}$ but also very dry years with less than $400 \mathrm{~mm}$. 1998 was clearly a very dry year. Extremely dry years have always been typical of this alpine region and results from climate models (Hu et al., 2000) suggest that interannual variability should be expected to increase in the future. As a result we suggest that droughts such as experienced in 1998 are part of the regional climate and can be expected to happen again in the future, at least as often as they did in the past.

Significant trends are present in the temperature data, particularly when considering the number of very hot days. Apart from contributing to the drought effect, higher summer temperatures at precisely the levels that have been experienced, i.e. average daily values higher than $20^{\circ} \mathrm{C}$, or maximum temperatures higher than $25^{\circ} \mathrm{C}$, have been reported as influencing the proliferation of nematodes which, particularly in association with drought, can be a cause of mortality in Scots pine stands (Bakke et al., 1991; Braasch, 1996). Higher Spring and Summer temperature is also likely to favour the frequently observed bark beetles Tomicus piniperda and Tomicus minor (Rigling et al., 1999; Rigling and Cherubini, 1999). In addition, an increase in winter minimum temperature, which has also been observed in Switzerland (Rebetez, 2001), will favour bark beetles as the minimum winter temperature has been found to limit bark beetle populations (Lombadero et al., 2000).

Potential evapotranspiration data have been measured independently but can be considered as a result of a combination of temperature and precipitation. The data exhibit a strong trend towards higher potential evapotranspiration values, probably due mainly to higher temperatures but also possibly to a light decrease in precipitation. The consequence is an increase in drought stress for vegetation in general and for Scots pine in particular.

The observed increase in temperature is clearly improving the conditions for pinewood nematodes and placing the central and upper Rhône Valley into the zone potentially threatened by pinewood nematodes (Rutherford et al., 1990). At the same time, bark beetles and other wood boring beetles that also serve as vectors for nematodes and stem infection fungi are also profiting from the increase in temperature and the shift of higher temperature to the springtime, which leads to faster larval development. In addition, increased transpiration in years with below-average precipitation will make trees more susceptible to attacks by secondary pathogens. If the increase in temperature continues, the potential stress to pines will increase further. With the recent introduction of the more aggressive Bursaphelenchus xylophilus to Europe (Portugal), the potential threat to pine forests has further increased (Motta et al., 1999).

\section{Conclusions}

The observed mortality rate of Scots pine in recent years was substantially higher than mortality rates that have been observed previously. We conclude that although high temperatures and drought are most likely not the only cause of the pine decline in the Swiss Rhône Valley, they may be the key factors leading to a shift in the complex balance between trees and secondary pathogens.

Our results indicate that whether through nematodes or other diseases, the stability of Scots pine 
stands is presently at great risk in the Swiss Rhône Valley, and that this situation is probably linked to climate change, particularly in the form of higher summer temperatures. The phenomenon occurring in the upper Rhône valley is very likely to be repeated in other dry alpine valleys.

The Scots pine forests in question grow on steep valley-side slopes, and they therefore have an important protective function for the human settlements below, against soil erosion and landslides. It is therefore particularly urgent not only to better understand the mortality through interdisciplinary research but also to find a means to change the species composition in order to establish tree species less sensitive to a warmer climate. This is because Scots pines are no longer adapted to the present climate in these regions. Native oak (Quercus pubescens), which has often been replaced by Scots pine as a result of past management activities, would be the most obvious choice of an alternative tree species.

Our analysis shows that the conditions experienced in 1998 can be expected to be repeated in the future. The probability of a hot summer is increasing. Dry years have always occurred in the past and should be at least as frequent in the future, whereas potential evapotranspiration values are clearly increasing. The high mortality rate and increased tree defoliation observed since 1996, but particularly after the hot and dry summer 1998, show that another summer with equivalent conditions could push this ecosystem into an alarming state if Scots pine is still the dominant tree species.

\section{Acknowledgements}

This work has been supported in part by the Forest Investigation Program, a joint project between the Swiss Federal Office of the Environment, Forests and Landscape (BUWAL, Bern) and the Swiss Federal Institute for Forest, Snow and Landscape Research (WSL, Birmensdorf). We are grateful to MeteoSwiss for providing the climatological data, to the various teams conducting the field assessments, to Andreas Rigling and John Innes for their encouraging and constructive comments and to Luzi Bernhard for the map in Figure 1.

\section{References}

Bakke A, Anderson RV, Kvamme T (1991) Pathogenicity of the Nematodes Bursaphelenchus xylophilus and Bursaphelenchus mucronatus to Pinus sylvestris seedlings: A Greenhouse Test. Scand J Forest Res 6: 407-412
Braasch H (1996) Pathogenitätstests mit Bursaphelenchus mucronatus an Kiefern- und Fichtensämlingen in Deutschland. Eur J Forest Pathol 26: 205-216

Bigler C, Bräker OU, Bugmann H, Dobbertin M, Rigling A (2004) Drought as an inciting mortality factor in Scots pine stands of the Valais, Switzerland. (Submitted)

Carron M (2000) Présence et diversité des champignons ophiostomatoïdes dans les pins (Pinus sylvestris L.) dépérissant en Valais. DS Thesis EPFZ, Zurich, 79 pp

Cech T, Perny B (1998) Kiefernsterben in Tirol. Forstschutz Aktuell 22: 12-15

Dobbertin M (1999) Relating defoliation and its causes to premature tree mortality. In: Forster B, Knizek M, Grodzki W (eds) Methodology of forest insect and disease survey in Central Europe. Proceedings of the Second Workshop of the IUFRO WP 7.03.10, April 20-23, 1999, Sion-Châteauneuf, Switzerland. Birmensdorf, Swiss Federal Institute for Forest, Snow and Landscape (WSL) pp 215-220

Dobbertin M, Brang P (2001) Crown defoliation improves tree mortality models. Forest Ecol Manag 141: $271-284$

Faes H (1921) Les dommages causes aux cultures par les usines d'Electro-chimie. Payot, Lausanne, $107 \mathrm{pp}$

Frei C, Davies HC, Gurtz J, Schär C (2001) Climate dynamics and extreme precipitation and flood events in Central Europe. Integrated Assessment 1: 281-299

Fujihara M (1996) Development of secondary pine forests after pine wilt disease, western Japan. J Veg Sci 7: 729-738

Hess E (1942) Die autochtonen Föhrenrassen des Wallis. Schweizerische Zeitschrift für Forstwesen 93: 1-16

Hu ZZ, Latif M, Roeckner E, Bengtsson L (2000) Intensified Asian summer monsoon and its variability in a coupled model forced by increasing greenhouse gas concentrations. Geophys Res Lett 27: 2681-2684

Kienast F (1982) Jahrringanalytische Untersuchungen in immissionsgefährdeten Waldschadengebieten des Walliser Rhonetales. Geographica Helvetica 3: 143-148

Kienast F, Schweingruber FH, Bräker OU, Schär E (1987) Tree-ring studies on conifers along ecological gradients and the potential of single-year analyses. Can J Forest Res 17: 683-696

Kontic R, Niederer M, Nippel CA, Winkler-Seifert A (1986) Jahrringanalysenan Nadelbäumen zur Darstellung und Interpretation von Waldschäden (Wallis, Schweiz). Ber. Eidg. Anst. forstl. Versuchswesen 283: 46

Kozlowski TT, Kramer PJ, Pallardy SG (1991) The physiological ecology of woody plants. San Diego: Academic Press, 657

Lombardero MJ, Ayres MP, Ayres BD, Reeve JD (2000) Cold tolerance of four species of bark beetle (Coleoptera: Scolytidae) in North America. Environ Entomol 29: 421-432

Mamiya Y (1988) History of pine wilt disease in Japan. J Nematol 20: 219-226

Motta MM, Braasch H, Bravo MA, Penas AC, Burgermeister W, Metge K, Sousa E (1999) First report of Bursaphelenchus xylophilus in Portugal and in Europe. Nematology 1: 727-734 
Müller E, Stierlin HR (1990) Sanasilva Kronenbilder mit Nadel- und Blattverlustprozenten. Eidgenössische Forschungsanstalt für Wald, Schnee und Landschaft, Birmensdorf

Pouttu A, Dobbertin M (2000) Needle retention and density patterns in Pinus sylvestris L. in the Rhone Valley of Switzerland: comparing results of the needle-trace method with visual defoliation assessments. Can J Forest Res 30: 1973-1982

Raison RJ, Khanna PK, Benson ML, Myers BJ, McMurtrie RE, Lang ARG (1992) Dynamics of Pinus radiata foliage in relation to water and nitrogen stress 2 . Needle loss and temporal changes in total foliage mass. Forest Ecol Manag 52: 159-178

Rebetez M (2001) Changes in daily and nightly day-today temperature variability during the twentieth century for two stations in Switzerland. Theor Appl Climatol 69: $13-21$

Rebetez M (1999) Twentieth century trends in droughts in southern Switzerland. Geophys Res Lett 26: 755-758

Rickli C, Schulin R, Attinger W, Flühler H (1989) Dekontamination ehemals fluorbelasteter Waldstandorte im Wallis. Bulletin de la Murithienne 107: 113-124

Rigling A, Cherubini P (1999) Wieso sterben die Waldföhren im Telwald bei Visp? Eine Zusammenfassung bisheriger Studien und eine dendroökologische Untersuchung. Schweizerische Zeitschrift für Forstwesen 150(4): 113-131

Rigling A, Waldner PO, Forster T, Bräker OU, Pouttu A (2001) Ecological interpretations of tree-ring width and intra-annual density fluctuations in Pinus sylvestris L. from dry sites of the Central Alps and Siberia. Can J Forest Res 31: 18-31

Rigling A, Forster B, Wermelinger B, Cherubini P (1999) Waldföhrenbestände im Umbruch. Wald und Holz 13: $8-12$

Rutherford TA, Webster JM (1987) Distribution of pine wilt disease with respect to temperature in North
America, Japan, and Europe. Can J Forest Res 17: 1050-1059

Rutherford TA, Mamiya Y, Webster JM (1990) Nematodeinduced pine wilt disease: factors influencing its occurrence and distribution. Forest Sci 36: 145-155

Scherrer HU, Flühler H, Mahrer F (1981) Alternative Verfahren für die Interpretation von Föhrenschäden (Pinus silvestris L.) aufmittelmaßstäblichen InfrarotFarbaufnahmen. Mitteilung Eidg. Anstalt für das Forstliche Versuchswesen 57: 433-452

Scherrer HU (1988) Waldveränderungen im Raum Visp 1892-1987, Fallbeispiele. Switzerland: Nesslau, 32 pp

Tomiczek A (1996) Beteiligung von Splintholznematoden am Kiefernsterben in Österreich. Forstschutz Aktuell 17/18: $15-16$

Vertui F, Tagliaferro F (1998) Scots pine (Pinus sylvestris L.) die-back by unknown causes in the Aosta Valley, Italy. Chemosphere 36: 1061-1065

Wermelinger B, Seifert M (1998) Analysis of the temperature dependent development of the spruce bark beetle Ips typographus (L.) (Col. Scolytidae). J Appl Entomol 122: 185-191

Wermelinger B, Seifert M (1999) Temperature-dependent reproduction of the spruce bark beetle Ips typographus, and analysis of the potential population growth. Ecol Entomol 24: 103-110

Zierl B (2000) WAWAHAMO a hydrological model to simulate drought in forested ecosystems. Ph.D. Thesis No. 1320, University of Fribourg, Switzerland. Edited by Swiss Federal Institute WSL, Birmensdorf, Switzerland, $189 \mathrm{pp}$

Authors' addresses: Martine Rebetez (e-mail: Rebetez@ wsl.ch), WSL Swiss Federal Research Institute, CP 96, CH-1015 Lausanne, Switzerland; Matthias Dobbertin, WSL Swiss Federal Research Institute, Zürcherstrasse 111, CH-8903 Birmensdorf, Switzerland. 